HJIMB Vol 1, No. 2 2019, pp: 18-23
https://doi.org/10.30606/hiimb
HIRARKI
Jurnal Ilmiah Manajemen dan Bisnis
http://iournal.upp.ac.id/index.php/Hirarki

\title{
PENGARUH PENGEMBANGAN KARIR, MOTIVASI DAN KOMPETENSI TERHADAP KINERJA PEGAWAI PUSKESMAS RAMBAH SAMO II
}

Muchlas Abror

Program Studi Manajemen, Universitas Pasir Pengaraian, Pasir Pengaraian, Indonesia.

\section{Info Artikel}

Sejarah Artikel:

Diterima 23 Agustus

2019

Disetujui 01 September

2019

Dipublikasikan

30 Oktober 2019

\section{Keywords:}

Pengaruh

pengembangan karir;

motivasi kerja;

kompetensi terhadap

kinerja pegawai

\begin{abstract}
Abstrak
Penelitian ini bertujuan untuk mengetahui pengeruh Pengembangan Karir, Motivasi Kerja dan Kompetensi terhadap Kinerja Pegawai pada Puskesmas di Kecamatan Rambah Samo II. Populasi dalam penelitian ini adalah seluruh pegawai Puskesmas di kecamatan Rambah Samo II. Sampel penelitian ini menggunakan teknik sampling jenuh dikenal juga degan istiah sensus, dengan jumlah sebanyak 54 orang pegawai. Variabel bebas dalam penelitian ini Pengembangan Karir (X1), Motivasi kerja (X2), dan Kompetensi (X3), variabel terikat Kinerja Pegawai (Y). Metode pengumpulan data menggunakan wawancara (interview), kuesioner (angket) dan observasi. Analisis data data menggunakan regresi linier berganda menggunakan program SPSS 20 diperoleh persamaan regresi yaitu $\boldsymbol{Y}=\mathbf{- 1 2 . 9 1 5}+\mathbf{0 , 4 5 8} X_{1}$ + 0,000 $X_{2}+0,977 X_{3}+$ e. Dari hasil pengujian dapat disimpulkan bahwa variabel pengembangan karir, motivasi kerja dan kompetensi berpengaruh signifikan terhadap kinerja pegawai pada Puskesmas di Kecamatan rambah Samo II.
\end{abstract}

\section{THE EFFECT OF CAREER DEVELOPMENT, MOTIVATION AND COMPETENCE ON THE PERFORMANCE OF EMPLOYEES PUSKESMAS RAMBAH SAMO II}

\begin{tabular}{|c|c|}
\hline & Abstract \\
\hline & $\begin{array}{l}\text { This study aims to determine the effect of Career Development, Work Motivation and } \\
\text { Competence on Employee Performance at Puskesmas in RambahSamo II Subdistrict.The } \\
\text { population in this study were all Puskesmas employees in RambahSamo II sub-district. The } \\
\text { sample of this study used a saturated sampling technique also known as the traditional } \\
\text { census, with a total of } 54 \text { employees. The independent variable in this study is Career } \\
\text { Development (X1), Work Motivation (X2), and Competence (X3), dependent variable } \\
\text { Employee Performance (Y). Methods of data collection using interviews (interviews), } \\
\text { questionnaires (questionnaires) and observation. Analysis of data data using multiple linear } \\
\text { regression using the SPSS } 20 \text { program obtained a regression equation that is } Y=-12,915+ \\
0,458 X 1+0,000 X 2+0,977 X 3+e \text {. From the test results it can be concluded that the } \\
\text { variables of career development, work motivation and competence have a significant effect } \\
\text { on employee performance at the Puskesmas in RambahSamo II District. }\end{array}$ \\
\hline${ }^{\otimes}$ Alamat korespondensi : & 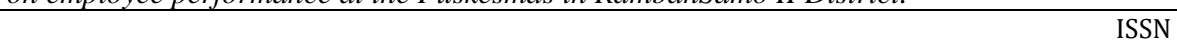 \\
\hline Universitas Pasir Pengaraia & $\begin{array}{r}\text { 2684-9666(cetak) } \\
2684-8503 \text { (online) }\end{array}$ \\
\hline
\end{tabular}




\section{PENDAHULUAN}

Pengembangan karir pada dasarnya sangatlah dibutuhkan pada Puskesmas di Kecamatan Rambah Samo II dikarenakan pengembangan karir berorientasi pada tantangan perkembangan teknologi di masa yang akan datang. Pengembangan karir mempunyai eksitensi di masa depan yang bergantung pada SDM karena SDM harus lakukan pembinaan karir pada pegawai yang dilaksanakan secara berencana dan berkelanjutan setiap tahunnya. Motivasi Kerja merupakan salah satu unsur penting dalam kepegawaian pada Puskesmas di Kecamatan Rambah Samo II, artinya Motivasi harus dimiliki oleh setiap pegawai. Menurut Wibowo (2010 : 379) motivasi kerja merupakan dorongan terhadap serangkaian proses prilaku manusia pada pencapain sebuah tujuan.Sedangkan unsur yang dalam motivasi itu sendiri meliputi unsur pembangkitan, menjaga, mengarahkan, menunjukkan intensitas bersifat terus menerus dan adanya tujuan.Kompetensi Karyawan merupakan hal yang patut di pertimbangkan pada Puskesmas di Kecamatan Rambah Samo II ketika melakukan proses rekrutmen, plotting, hingga pertimbangan kompetensi karyawan. Selain itu, ketidak sesuaian Kompetensi Karyawan atas dasar latar belakang pendidikan dan ketrampilan karyawan dengan pekerjaan juga dapat membuat karyawan-karyawan tersebut menjadi tidak nyaman dengan posisi pekerjaan dibidangnya. Pengertian kinerja (performance) merupakan gambaran mengenai tingkat pencapaian pelaksaan suatu program kegiatan atau kebijakan dalam mewujudkan sasaran, tujuan, visi dan misi organisasi yang dituangkan melaui perencanaan strategis pada Puskesmas di Kecamatan Rambah Samo II. Kinerja pegawai dapat diketehui dan diukur jika individu atau sekelompok pegawai/karyawan telah mempunyai kriteria atau stendar keberhasilan tolak ukur yang telah ditetapkan pada Puskesmas di kecamatan rambah Samo II. Adapun tujuan dari penelitian ini dengan melihat latar belakang masalah dan rumusan masalah diatas Untuk mengetahui bagaimana pengaruh pengembangan karir terhadap kinerja pegawai pada puskesmas di kecamatan Rambah Samo II. Untuk mengetahui bagaimana pengaruh motivasi kerja terhadap kinerja pegawai pada puskesmas di kecamatan rambah Samo II. Untuk mengetahui bagaimana pengaruh kompetensi terhadap kinerja pegawai pada puskesmas di kecamatan Rambah Samo II. Untuk mengetahui bagaimana pengaruh pengembangan karir, motivasi kerja dan kompetensi terhadap kinerja pegawai pada puskesmas di kecamatan Rambah Samo II.

Adapun penelitian ini mencakup berbagai macam manfaat yaitu, Manfaat teoritis yaitu Hasil penelitian di harapkan dapat bermanfaat dan memberi konrtibusi untuk mengembangkan ilmu pengetahuan secara umum, khususnya manajemen sumber daya manusia, yang berkaitan dengan masalah pengembangan karir, motivasi kerja, kompetensi dan kinerja pegawai, Manfaat praktis yaitu Manfaat praktis di tunjukkan bagi instansi terkait, yaitu pada puskesmas di kecamatan Rambah Samo supaya dapat di jadikan sebagai bahan masukan instansi, Manfaat kebijakan yaitu Gambaran penelitian ini di harapkan dapat menjadi bahan kebijakan apa yang harus dilakukan oleh instansi pada puskesmas di kecamatan Rambah Samo II.

Kinerja pegawai merupakan perwujudan yang dilakukan oleh para pegawai untuk mencapai tujuan didalam sebuah organisasi sesuai dengan prosedur yang telah ditetapkan oleh organisasi. Beberapa penelitian terdahulu hasil penelitian oleh Gita Sicilia (2015) dalam 
judul Pengaruh Kepemimpinan, Pengembangan Karir dan Motivasi Terhadap Kepuasan Kerja Karyawan Bank Riau cabang utama Pekan Baru. Hasil penelitian menujukan bahwa Pengaruh Kepemimpinan, Pengembangan karir, dan Motivasi Terhadap Kinerja di Bank Riau Kepri cabang utama Pekan Baru berpengaruh positif dan signifikan, Hasil penelitian oleh Abubakar (2017) dalam judul Pengaruh Kompetensi Pegawai Terhadap Prokdutifitas Kerja Pegawai Dinas Kesehatan Kota Bandung. Hasil penelitian menujukan bahwa pengaruh kompetensi pegawai berpengaruh positif terhadap prokdutivitas kerja pegawai pada Dinas Kesehatan Kota Bandung, Hasil penelitian oleh judul Farida (2012) dalam penelitian Pengembangan Karir Terhadap kinerja Pegawai Negri Sipil Studi di Kota Bandar Lampung. Hasil penelitian menujukan bahwa pengaruh terbesar dari variabel tersebut adalah variabel pendidikan formal, sedangkan ruang terkecil adalah adanya lowongan jabatan.

\section{METODE}

Objek dalam penelitian ini adalah seluruh pegawai puskesmas pada kecamatan rambah samo yang berjumlah 54 orang pegawai/karyawan. Desain sampel yang digunakan dalam penelitian ini adalah sampling jenuh, dimana semua pegawai akan dijadikan sebagai sampel. Metode yang digunakan dalam penelitian ini adalah metode sensus.

Tekhnik pengambilan data yang yang digunakan adalah sebagai berikut: Metode wawancara (interview): Tekhnik pengumpulan data ini apabila peneliti ingin melakukan studi pendahuluan untuk menemukan permasalahan yang harus diteliti, dan juga apabila peneliti ingin mengetahui hal-hal dari responden yang lebih mendalam dan jumlah respondennya sedikit atau kecil (Sugiyono, 2014 : 224). Dalam metode wawancara ini peneliti harus melakukan Tanya jawab secara langsung kepada pihak yang berwenang pada puskesmas dikecamatan rambah samo, Metode kuisioner (angket): Kuisioner merupakan tekhnik pengumpulan data yang efisien bila peneliti tahu dengan pasti variabel yang akan diukur dan tahu apa yang bisa diharapkan dari responden (Sugiono, 2014 : 230). Dalam penelitian ini menggunakan pertanyaan tertutup yang diberikan kepada seluruh pegawai pada puskesmas dikecamatan rambah samo,Metode observasi: Menurut Notoatmojo (2010 : 131) metode observasi (pengamatan) adalah suatu hasil pembuatan jiwa secara aktif dan penuh perhatian untuk menyadari adanya rangsangan. Maksud dari para ahli diatas meliputi melihat, mendengar, dan mencatat sejumlah taraf aktifitas tertentu atau situasi tertentu yang ada hubungannya dengan masalah yang akan diteliti.

\section{HASIL DAN PEMBAHASAN}

Yang menjadi responden dalam penelitian ini adalah seluruh pegawai puskesmas rambah samo II. Kuesioner yang diolah adalah 54 orang pegawai. Responden terbanyak berdasarkan jenis kelamin adalah: berjenis kelamin perempuan sebesar 41 responden (75,9\%), berdasarkan pendidikan adalah: D-III berjumlah 32 responden $(59,2 \%)$, sedangkan berdasarkan usia adalah: yang berusia 18 s.d 25 tahun berjumlah 36 responden $(66,7 \%)$.

Untuk mengetahui tingkat Capaian Responden peneliti menggunakan metode: Ranking Mehod yang dikemukakan oleh Martoyo (2007 : 93), yaitu suatu metode penelitian dengan cara menyusun orang yang dinilai berdasarkan tingkatnya pada beberapa sifat yang dinilai yaitu suatu skala pengukuran yang 
pada umumnya menunjukkan lima tingkat suatu sifat tertentu.

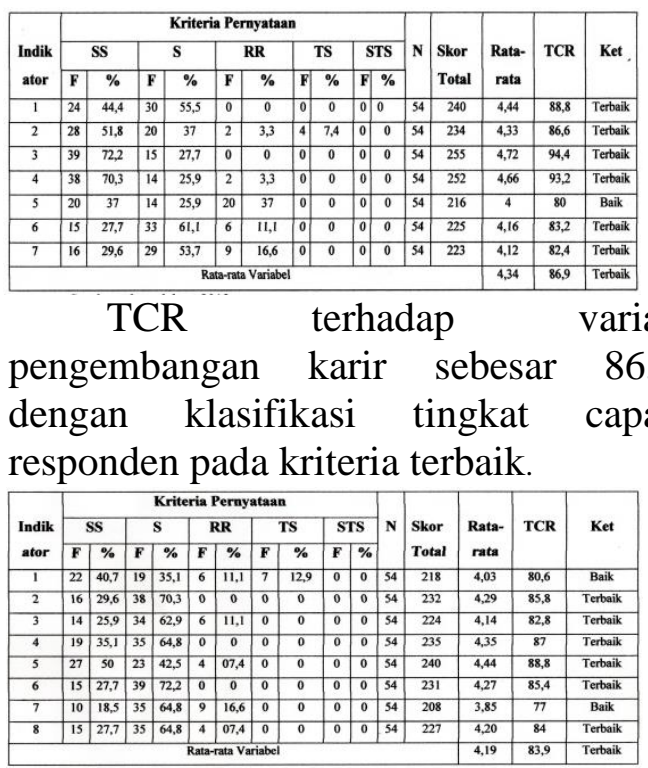

TCR terhadap variabel motivasi kerja sebesar 83,9\% dengan klasifikasi tingkat capaian responden pada kriteria terbaik.

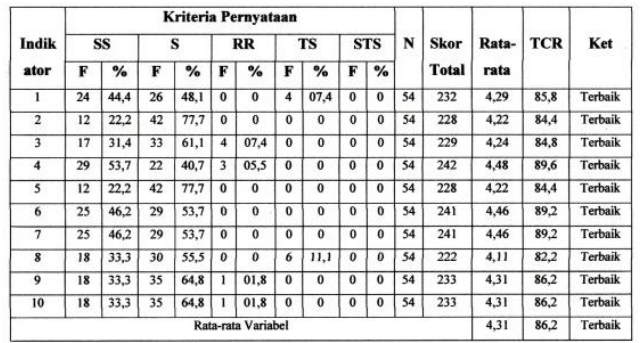

TCR terhadap variabel kompetensi sebesar 86,2\% dengan klasifikasi tingkat capaian responden pada kriteria terbaik.

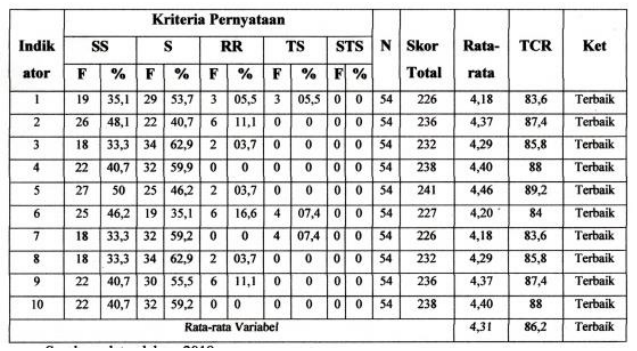

TCR terhadap variabel kinerja pegawai sebesar $86,2 \%$ dengan klasifikasi tingkat capaian responden pada kriteria terbaik.

\section{Uji Validitas dan Reliabilitas}

Pengujian validitas dalam penelitian ini dilakukan dengan korelasi pearson validity dengan teknik product moment yaitu setiap sekor tiap item dikorelasikan dengan skor total.

Berdasarkan uji Validitas semua kuisioner yang digunakan dalam penelitian ini adalah valid. Pengujian Reliabilitas dilakukan untuk menunjukkan sejauh mana suatu hasil pengukuran relative kuisioner.

Uji signifikan dilakukan pada taraf $\alpha=0,05$. Uji reliabilitas menggunakan teknik Cronbach Alpha, dengan ketentuan reliable apabila koefisien $\alpha>$ 0,6.Dari hasil uji reliabilitas dalam penelitian ini semua variable yang digunakan adalah reliable.

\section{Uji Asumsi Klasik}

Dari hasil uji normalitas menggunakan one-sample kolmogrovsmirnov test menunjukkan bahwa nilai signifikansi sebesar 0,037 lebih besar dari 0,05 maka dapat diketahui bahwa semua variabel yang digunakan dalam penelitian ini terdistribusi secara normal.

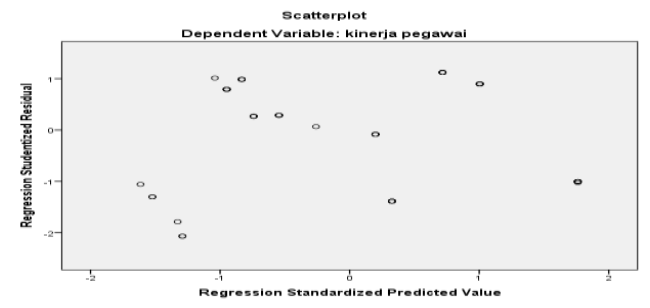

Ujiheteroskedastisitas

dapatdisimpulkanbahwatitik-titik

menyebar secara acak serta tersebar diatas maupun dibawah angka 0 pada sumbu Y, serta tidak mempunyai pola yang jelas atau tidak membentuk suatu pola. Untuk itu dapat disimpulkan bahwa tidak terjadi heteroskedasitas pada model regresi, sehingga model regresi layak dipakai sebagai prediksi.

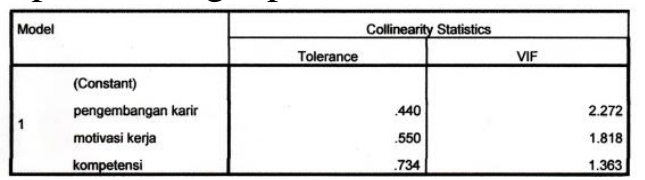


Hasil uji multikolonearitas terlihat bahwa nilai tolerance semua variabel lebih besar dari 0,10 , dan nilai VIF semua variabel lebih kecil dari 10. Maka dapat disimpukan bahwa dalam penelitian ini tidak terdapat multikolinieritas antara variabel independen dalam model regresi.

\section{Analisis Regresi Linier Berganda}

\begin{tabular}{|c|c|c|c|c|c|c|}
\hline \multirow[t]{2}{*}{ Mode } & & \multicolumn{2}{|c|}{$\begin{array}{l}\text { Unstandardized } \\
\text { Coefficients }\end{array}$} & \multirow{2}{*}{$\begin{array}{c}\begin{array}{c}\text { Standardized } \\
\text { Coefficients }\end{array} \\
\text { Beta } \\
\end{array}$} & \multirow[t]{2}{*}{$t$} & \multirow[t]{2}{*}{ Sig. } \\
\hline & & B & Std. Error & & & \\
\hline \multirow{4}{*}{1} & (Constant) & -12.915 & 3.811 & & -3.389 & .001 \\
\hline & pengembangan karir & .458 & .160 & .227 & 2.865 & .006 \\
\hline & motivasi kerja & .000 & .126 & .000 & .004 & .997 \\
\hline & kompetensi & .977 & 076 & .792 & 12.888 & .000 \\
\hline
\end{tabular}

Berdasarkan hasil analisis diperoleh persamaan regresi linear berganda: $Y=$ $12.915+0,458 \mathrm{X}_{1}+0,000 \mathrm{X}_{2}+0,977$ $\mathrm{X}_{3}+$ e. Kostanta sebesar -12.915 menyatakan bahwa jika pengembangan karir, motivasi kerja dan kompetensi nilainya adalah 0 , maka kinerja pegawai akan bernilai sebesar -12.915.Koefisien regresi pengembangan karir (X1) menujukkan angka 0,458, artinya jika variabel pengembangan karir naik $1 \%$ maka akan meningkatkan kinerja pegawai sebesar 0,458, Koefisien regresi motivasi kerja (X2) menujukkan angka 0,000, artinya jika variabel motivasi kerja naik $1 \%$ maka akan meningkatkan kinerja pegawai sebesar 0,000, Koefisien regresi kompetensi (X3) menujukkan angka 0,977, artinya jika variabel motivasi kerja naik $1 \%$ maka akan meningkatkan kinerja pegawai sebesar 0,977 .

Uji-t

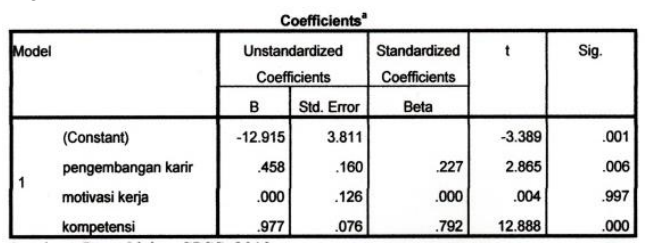

Uji t untuk variabel pengembangan karir diperoleh thitung sebesar 2,865 lebih besar jika dibandingkan dengan ttabel sebesar 2,00665 atau besarnya signifikansi untuk variabel pengembangan karir (X1) adalah sebesar 0,006 menujukkan bahwa lebih kecil dari $\alpha$ yaitu sebesar 0,05 . Dari hasil pengujian dapat disimpulkan bahwa variabel pengembangan karir berpengaruh signifikan terhadap kinerja pegawai. dengan demikian maka Ho ditolak H1 diterima. Uji t untuk variabel motivasi kerja diperoleh thitung sebesar 0,004 lebih kecil jika dibandingkan dengan ttabel sebesar 2,00665 atau besarnya signifikansi untuk variabel motivasi kerja (X2) adalah sebesar 0,997 menujukkan bahwa lebih besar dari $\alpha$ yaitu sebesar 0,05. Dari hasil pengujian dapat disimpulkan bahwa variabel motivasi kerja tidak berpengaruh terhadap kinerja pegawai. dengan demikian maka Ho diterima $\mathrm{H} 2$ ditolak. Uji t untuk variabel kompetensi diperoleh thitung sebesar 12,888 lebih besar jika dibandingkan dengan ttabel sebesar 2,00665 atau besarnya signifikansi untuk variabel kompetensi (X3) adalah sebesar 0,000 menujukkan bahwa lebih kecil dari $\alpha$ yaitu sebesar 0,05. Dari hasil pengujian dapat disimpulkan bahwa variabel kompetensi berpengaruh signifikan terhadap kinerja pegawai. Dengan demikian maka Ho ditolak H3 diterima.

\section{Uji F}

\begin{tabular}{|c|c|c|c|c|c|c|}
\hline \multicolumn{7}{|c|}{ ANOVA" } \\
\hline Mor & & Sum of Squares & df & Mean Square & $\mathrm{F}$ & sig. \\
\hline & Regression & 1326.227 & & 442.076 & 103.641 & $.000^{\circ}$ \\
\hline 1 & Residual & 213.273 & 5 & 4.265 & & \\
\hline & Total & 1539500 & 5 & & & \\
\hline
\end{tabular}

Dengan menggunakan pengujian $\mathrm{F}$ maka dapat diketahui apakah semua variabel independen mempunyai pengaruh secara bersamaan terhadap variabel dependen.uji $F$ menujukkan bahwa nilai Fhitung sebesar 103,641 sedangkan Ftabel sebesar 2,79 dilihat dari tingkat signifikan 5\% dengan derajat kebebasan df (4-1) = 3 dan df 2 (54-3-1) $=50$. Karena $\mathrm{F}$ hitung $>\mathrm{F}$ tabel dan tingkat signifiansi $0,000<0,05$, artinya 
Ho ditolak H4 diterima. Maka dapat disimpulkan bahwa pengembangan karir, motivasi kerja dan kompetensi secara simultan berpengaruh terhadap kinerja pegawai.

\section{Uji Determinasi $\left(\mathbf{R}^{\mathbf{2}}\right)$}

koefisien determinasi ini digunakan untuk mengetahui seberapa besarnya persentase hubungan variabel independen terhadap variabel dependen.

\section{KESIMPULAN}

Berdasarkan hasil penelitian yang dilakukan penelitian pada pegawai Puskesmas di Kecamatan Rambah Samo, dengan jumlah sampel 54 orang Pegawai didapatkan kesimpulan yaitu: Dari hasil pengujian dapat disimpulkan bahwa variabel pengembangan karir berpengaruh signifikan terhadap kinerja pegawai pada Puskesmas di Kecamatan Rambah Samo II, Dari hasil pengujian dapat disimpulkan bahwa variabel motivasi kerja tidak berpengaruh terhadap kinerja pegawai pada Puskesmas di Kecamatan Rambah Samo II, Dari hasil pengujian dapat disimpulkan bahwa variabel kompetensi berpengaruh signifikan terhadap kinerja pegawai pada Puskesmas di Kecamatan Rambah Samo II, Dari hasil pengujian dapat disimpulkan bahwa variabel pengembangan karir, motivasi kerja dan kompetensi berpengaruh signifikan terhadap kinerja pegawai pada Puskesmas di Kecamatan rambah Samo II.

\section{SARAN}

Berdasarkan hasil analisis dalam penelitian ini, maka peneliti mengajukan beberapa saran antara lain, Perlu dilakukan peningkatan dalam pengembangan karir, motivasi kerja dan kompetensi oleh setiap pegawai pada puskesmas dikecamatan Rambah Samo II. Bagi peneliti selanjutnya diharapkan dapat menambahkan sampel

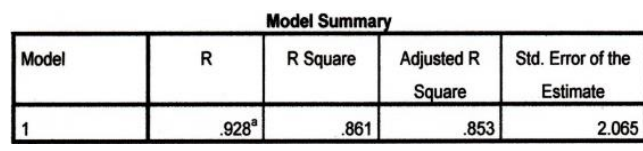

Berdasarkan uji deteminasi $\left(\mathrm{R}^{2}\right)$ menujukkan angka adjusted $R$ square 0,853 atau $85,3 \%$ yakni berati variasi variabel pengembangan karir, motivasi kerja dan kompetensi , sisanya 0,147 atau 14,7 \%dapat dijelaskan oleh variabel lain di luar dari variabel penelitian

dalam penelitiannya, karena semakin banyak sampel yang diambil maka hasil yang didapatkan semakin akurat dan terpercaya.

\section{DAFTAR PUUSTAKA}

Hasibuan, melayu S.P (2011). Manajemen sumber daya manusia.edisi revisi. Jakarta : Bumi aksara

Puskesmas Rambah SamoII. (2018). Desa rambah utama. Kecamatan Rambah Samo II. Kabupaten Rokan Hulu

Rivai,Veitzal dan sagala, Ella Jauvani (2009). Manajemen sumber daya manusia untuk perusahaan : dari teori ke praktek

Wibowo. (2010). Manajemen kinerja. Jakarta : Rajawali Pers

Torang, Syamsir. (2013). Organisasi dan manajemen, Bandung : penerbit Alvabeta

Sunyoto, Danang. (2012). Manajemen sumber daya manusia. Yogyakarta : penerbit Nuba medika

Sinambela, Lijan poltak. (2016). Manajemen sumber daya manusia.Jakarta : penerbit Bumi Aksara

Pustakarya Subekhi Akhmaddan jauhar, Mohamad. (2012). Pengantar manajemen sumber daya manusia.Jakarta : penerbit Prestasi

Sugiyono. (2014). Metode penelitian kuantitatif, kualitatif, dan $R \quad \&$ $D$.Bandung : penerbit Alfabeta 
Juwita (2016). Pengaruh pengembangan karir terhadap prokdutivitas pegawai rumah sakit umum daerah kabupatan Rokan Hulu. perpustakaan universitas Pasir Pengaraian

Suwatno dan Priansa, Donni Juni. (2011). Manajemen sumber daya manusia dalam organisasi publikasi dan bisnis.Bandung : penerbit alfabeta

Rodlial Ramadhan Tachbir Abubakar.pengaruh kompetensi pegawai terhadap prokdutivitas kerja pegawai dinas kesehatan kota bandung. Jurnal admistrasi Negara, Vol, 24 Nomor 1, April 2018

Gita sicilia dan Marzolina. Pengaruh kepemimpinan, pengembangan karir dan motivasi terhdap kepuasan kerja karyawan Bank Riau kepri cabang utama Pekan baru. Vol, 7 No 1 januari 2015 Tepak manajemen Bisnis

Ridwan Purnama. Pengaruh motivasi kerja terhadap prokdutivitas kerja karyawan pada bagian produksi $C V$. Epilson Bandung. Vol, 7 No 14 September 2008

Ita Rifiani Permatasari. Pengaruh pengembangan karir terhadap kinerja karyawan ( studi kasus di PT.Telkom Malang ). Vol, 2 No 3 Oktober 2006

Gusmi (2018). Pengaruh Gaya Kepemimpunan dan Komunikasi Terhadap Kinerja Karyawan pada kantor Camat Rambah samo. Perpustakaan Universitas Pasir Pengaraian. 